\title{
RESPONSABILIDAD PENAL DEL ASESOR JURÍDICO
}

\author{
Prof. Dr. Dr. h. c. Diego-Manuel Luzón Peña \\ Catedrático de Derecho Penal. Universidad de Alcalá \\ diegom.luzon@uah.es
}

Resumen: El presente artículo muestra al lector un panorama de las distintas responsabilidades, genéricas y especificas, en las que puede incurrir un asesor jurídico como consecuencia del ejercicio de las funciones propias de su cargo.

Summary: This article shows the reader a view of the different generic and specific liabilities, in which a legal counselor can be liable for as a consequence of his actions when exercising his profession.

Palabras clave: Derecho penal / responsabilidad / asesor jurídico / delito.

Key words: Criminal Law / liability / Legal counselor / crime.

Tabla de Contenido: I. Introducción; II. Actuaciones perjudiciales para el cliente; 1. Figuras delictivas especificas, 2. El asesoramiento que induce a error al cliente, III. Actuaciones favorables al cliente; 1 . Asesoramiento y favorecimiento activo de conducta delictiva del cliente. Delimitación entre participación e intervención punible y ejercicio legitimo de la profesión o al menos conducta penalmente atípica. 2. Omisiones respecto de la conducta delictiva del cliente, IV. Apéndice: Resoluciones Jurisprudenciales; 1. Sentencias sobre conductas de prestaciones neutras o de cooperación delictiva en diversos campos, 2. Sobre el carácter de participación criminal o no de la cooperación del asesor jurídico, 3. Actuaciones de cooperación muy especifica, al margen del estándar profesional normal. 


\section{Introducción}

Del amplio elenco de cuestiones que suscita la responsabilidad jurídica y penal de los asesores jurídicos, abogados o no, seleccionaremos sólo algunas y vamos a dejar fuera de entrada cuestiones específicas como las de la responsabilidad en relación con el blanqueo de capitales, la responsabilidad de los asesores fiscales y los límites éticos y deontológicos de la actuación del asesor jurídico.

Aquívamos a examinar, por una partelas posibles responsabilidades en que puede incurrir un abogado o, de modo más amplio, un asesor jurídico por conductas que perjudiquen a sus clientes, particulares o a las empresas asesoradas y en su caso a sus directivos, supuestos en que su posible responsabilidad penal por diversos delitos será como regla general a título de autor de una actuación dolosa o imprudente; y por otra parte las conductas del asesor en un sentido favorable al cliente asesorado en una actividad que puede constituir delito, casos en los que se plantea, en primer lugar, la cuestión de los límites entre la intervención, generalmente participación punible (inducción o cooperación) del asesor y la conducta atípica o justificada de éste, y en segundo lugar la cuestión de si pueden existir responsabilidades del asesor por omisión respecto de la conducta delictiva del cliente.

Hay que indicar que, excepto en algunas figuras típicas concretas en que sí puede tener relevancia especial que el asesor jurídico sea un abogado actuando como tal, en la mayoría de los supuestos es indiferente que el sujeto que asesora sea un abogado colegiado desempeñando una actuación específica como tal, o que se trate de cualquier otro asesor jurídico que orienta de modo amplio en cuestiones jurídicas a la dirección de la empresa, y tanto si trabaja como empleado de ésta como si es únicamente aun asesor externo.

\section{Actuaciones perjudiciales para el cliente}

\section{Figuras delictivas específicas}

a) Por una parte el asesor puede cometer conductas delictivas genéricas contra bienes jurídicos o intereses de sus clientes, de la empresa o de sus directivos, aprovechando precisamente el conocimiento que tiene de éstos y de su funcionamiento. En tales casos responderá de los correspondientes delitos, p.ej. falsedades documentales, delitos patrimoniales diversos como hurtos, robos, apropiaciones indebidas, estafas, o delitos contra el honor o la intimidad de la propia persona jurídica o de las personas físicas de los directivos, como autor si realiza la conducta típica o como partícipe de una autoría ajena, pero con la peculiaridad de la agravación de su responsabilidad precisamente por el abuso de su función: en unos casos se le aplicará la agravante genérica de abuso de confianza del art. $22,6 .^{\mathrm{a}} \mathrm{CP}$, en otros se le aplicará un subtipo agravado como en la estafa cualificada del art. 250.1, $7 .^{\circ}$ porque haya "abuso de las relaciones personales existentes 
entre víctima y defraudador, o aproveche éste su credibilidad empresarial o profesional", y en otros supuestos precisamente la posición de confianza supondrá ser, además de asesor, el administrador de bienes o de una sociedad y ello precisamente le podrá convertir a tal sujeto en autor de un delito de apropiación indebida del art. 252 o en un delito societario como la administración desleal del art. 295 CP.

b) Por otra parte, existen figuras delictivas específicas que tipifican actuaciones ilícitas del profesional o del abogado.

Así la revelación del secreto profesional del art. 199.2 CP ("el profesional que, con incumplimiento de su obligación de sigilo o de reserva, divulgare los secretos de otra persona"), que afecta por igual a abogados y asesores externos a la empresa, y para los que trabajan como empleados dentro de la propia asesoría jurídica de la empresa, en principio parecería aplicable la figura algo más leve de la revelación del secreto de empresa del art. 199.1 ("el que revelare secretos ajenos, de los que tenga conocimiento por razón de su oficio o sus relaciones laborales"); no obstante, o concurso leyes alternatividad o incluso concurso ideal de delitos. Colisión de deberes con obligación de denunciar delitos o de colaborar con Justicia, desobediencia y denegación auxilio: límites

c) Y como delitos más específicamente relacionados con los profesionales del Derecho, dentro del Tít. XX del libro II sobre los delitos contra la Administración de Justicia figura el Cap. VII "De la obstrucción a la Justicia y la deslealtad profesional". En el mismo se tipifican primero en los arts. 463 a 466 actuaciones obstructoras de la justicia, realizadas entre otros por abogado o procurador, que, además de perjudicar a la Administración de justicia y eventualmente a terceros, en ocasiones perjudicarán precisamente a sus clientes como la incomparecencia injustificada provocando la suspensión del juicio o la revelación de actuaciones procesales secretas, o más raramente - porque generalmente serán en beneficio del cliente- las violencias o intimidación contra otras partes o personas en el proceso, la destrucción u ocultación de documentos de la causa.

d) Pero sobre todo, en segundo lugar, en el art. 467 se tipifican dos formas de la antiguamente denominada "prevaricación de abogado y procurador" cuando el $\mathrm{CP}$ anterior la incluía entre las formas de prevaricación ${ }^{30}, \mathrm{y}$ que la propia rúbrica del Cap VII llama "deslealtad profesional", que algunos denominan "deslealtad profesional en sentido estricto" ${ }^{11}$, porque

$30 \quad$ Así en el art. 360 CP 1944/1973 agrupada junto con las otras formas de prevaricación judicial y funcionarial de los arts. 356 ss. Así se denominaba p. ej. en Rodríguez Devesa/Serrano (1995, p. 1139 ), Derecho Penal español, Parte Especial (PE), $18^{\mathrm{a}}$ ed., 1995, 1139 ss. Considera impropia esa denominación Quintero, en Quintero/Morales, Comentarios a la PE del D. Penal, 1999, 1382.

31 Así Orts, en Vives/Orts/Carbonell/G. Cussac/Martínez-Buján, Derecho Penal, Parte Especial, 2004, 977 ss. 
también consideran deslealtad profesional la destrucción de documentos y actuaciones o la revelación de actuaciones secretas ${ }^{32}$. Esta deslealtad reviste dos modalidades: la defensa de intereses contrarios del 467.1 y el perjuicio manifiesto doloso o imprudente de intereses encomendados (modalidad también denominada "incuria"33) del 467.2.

d.1) La primera modalidad del art. 467.1 castiga la actuación de "el abogado o procurador que, habiendo asesorado o tomado la defensa o representación de alguna persona, sin el consentimiento de ésta defienda o represente en el mismo asunto a quien tenga intereses contrarios". Esta deslealtad profesional se sostiene con razón que ha de interpretarse restrictivamente, para que no sea un delito meramente formal, exigiendo que la simultánea o posterior defensa o representación de persona con intereses contrarios sea perjudicial para el otro cliente ${ }^{34}$; pero ocurre que, por haber defendido o asesorado a éste, el abogado tendrá conocimientos derivados de esa especial relación de confianza ${ }^{35}$, por lo que en la práctica ello supondrá en la inmensa mayoría de los casos precisamente que los utilizará o le resultará dificilísimo abstraerse de tales informaciones y no tenerlas en cuenta en la defensa de los intereses contrarios, con lo que se producirá casi siempre el carácter perjudicial y la deslealtad o traición frente al cliente previo.

d.2) Y la modalidad del art. 467.2 tipifica en el párr. $10^{\circ}$ la conducta dolosa de "el abogado o procurador que, por acción u omisión, perjudique de forma manifiesta los intereses que le fueren encomendados"; sancionando con menor pena el párr. 2. "si los hechos fueren realizados por imprudencia grave”. Esta causación activa u omisiva de perjuicio manifiesto a los intereses del cliente, dolosa o gravemente imprudente, tendrá una gran importancia para exigir responsabilidad penal por infracciones ostensiblemente lesivas en la labor de asesoramiento jurídico del cliente; constituye una forma genérica de tipificación de cualesquiera conductas intolerablemente perjudiciales y por ello patentemente desconsideradas, desleales y lesivas para con esos intereses, y supondrá una cláusula de recogida de las infracciones profesionales más graves frente al cliente no previstas en los artículos anteriores.

32 Orts, en Vives/Orts/et al., PE, 2004, 975 s.; Muñoz Conde, DP, PE, 17. a, 2009, 879 ss. En cambio, González Rus, en Cobo (coord.), DP español, PE, 2. ${ }^{\text {a }, ~ 2005, ~} 985$ ss., sólo llama deslealtad profesional a las figuras del art. 467.

33 Quintero, en Quintero/Morales, Comentarios PE, 1999, 1385, la llama "incuria intencional y la negligente".

34 Así Quintero, en Quintero/Morales, Comentarios PE, 1999, 1384, citando la STS 6-7-1970, Ar 3202. La STS 26-11-1999 exige que la conducta del abogado haya al menos creado un peligro concreto para los intereses de la parte que defiende. 
La causación de perjuicio para el cliente, que puede ser no sólo material o económico, sino también jurídico o moral, como reconoce la jurisprudencia (STS 30-10-1980, 25-6-1993, 1-2-2000, 14-7-2000, ha de ser "de forma manifiesta", lo que implica no sólo gravedad en sus repercusiones, sino que se trate de perjuicios "palpables, patentes, palmarios u ostensibles" (STS 14-7-2000). No basta que ex post los intereses del cliente sufran un perjuicio p. ej. por una resolución judicial favorable, sino que la actuación del abogado ha de ser ex ante adecuada o idónea para causar tal perjuicio manifiesto -adecuación como exigencia de la imputación objetiva-, y más aún, que rebase el riesgo permitido por no suponer una actuación conforme a la diligencia debida del profesional, sino incorrecta y contraria a las reglas del ejercicio legítimo de la profesión.

Hablar de deslealtad es más evidente en la conducta dolosa del párrafo $1 .^{\circ}$ del art. 467.2, que puede ser ciertamente intencional o con dolo directo, pero también y más frecuentemente con dolo eventual, aceptando el abogado o no rechazando la posibilidad representada de perjudicar manifiestamente al cliente. Pero también se puede hablar de deslealtad para con el cliente en sentido amplio en la modalidad del párr. $2 .^{\circ}$, de causarle por imprudencia grave ese perjuicio manifiesto, donde también se podrá hablar de incuria, negligencia o incompetencia o impericia profesional ${ }^{36}$, que efectivamente serán las formas más frecuentes de esa imprudencia grave. La misma podrá ser imprudencia inconsciente, pero también en algunos casos imprudencia consciente si el asesor se representa la posibilidad de perjudicar gravemente los intereses del cliente pero confía con un mínimo de fundamento aunque equivocadamente en que no producir el perjuicio ${ }^{37}$; ciertamente serán raros los supuestos de confianza mínimamente fundada en no perjudicar, dado que se trata de perjuicio manifiesto, por lo que la conciencia de esa posibilidad casi siempre implicará dolo eventual.

Dichas figuras de causación dolosa o imprudente de perjuicios manifiestos al cliente del art. 467.2 están en concurso de leyes con la defensa de intereses contrarios del art. 467.1, que es una forma más específica de deslealtad y perjuicio al cliente (relación de especialidad del art. 8, $1 .^{\mathrm{a}} \mathrm{o}$, si se prefiere, dado que formalmente la descripción típica de ambas no es coincidente con un elemento específico en una, relación de subsidiariedad tácita del art. 8, 2. ${ }^{\mathrm{a}} \mathrm{CP}$ ): Y puede estar en concurso de delitos, real si son acciones separadas o ideal si se realiza con la misma acción, con otros delitos contra intereses de la administración de justicia o con otros delitos

36 Destacan la posibilidad tanto de negligencia como de impericia profesional González Rus, en Cobo (coord.), PE, 2. ${ }^{\text {, }}$ 2005, 987; Orts, en Vives/Orts/et al., PE, 2004, 979; Quintero, en Quintero/Morales, Comentarios PE, 1999, 1385, pero también habla de incuria intencional y negligente.

37 Así la teoría restringida del consentimiento o aceptación, que defiendo y que exige, para que haya imprudencia consciente y no dolo eventual, que la confianza en no realizar el tipo tenga un mínimo de fundamento racional: cfr. Luzón Peña, Curso DP, PG I, 1996, 426 s. 
muy diversos, como fraudes, falsedades, ataques a la intimidad o el honor del cliente, etc., por tratarse de bienes jurídicos distintos. Y por esa misma razón, como veremos más adelante (infra 2.), la causación de perjuicio manifiesto puede estar en concurso ideal con el delito en el que el abogado o asesor pueda incurrir en los casos en que, por inducir a error al cliente, le lleve a cometer la parte objetiva de un tipo delictivo.

d.3) En ambos casos, de los aps. 1 y 2 del art. 467, se trata de conductas del "abogado o procurador"; y respecto del abogado se plantea la cuestión de si el término se refiere sólo al abogado colegiado o si por el contrario comprende también al asesor jurídico relacionado con algún vínculo contractual, laboral o de servicios, con el cliente, en nuestro caso la empresa. La jurisprudencia no se pronuncia expresamente, pero se suele ocupar de casos de abogados colegiados, casi siempre en actuaciones procesales, aunque a veces en otras funciones de asesoramiento o apoyo jurídico. En la doctrina, unos no se pronuncian expresamente ${ }^{38}$, mientras que otros interpretan que ha de tratarse de quienes tengan formalmente la categoría de abogado o procurador mediante la inscripción e integración en el correspondiente colegio profesional ${ }^{39}$.

Realmente existen argumentos posibles en favor de ambas opciones. Por una parte se puede aducir que procede una interpretación restrictiva de abogado como aquel licenciado en Derecho que se haya colegiado precisamente para poder no sólo asesorar y apoyar jurídicamente a otros, sino para ejercer su defensa y a veces representación en un proceso, y que ello es así por coherencia sistemática con otros arts. de este Cap. VII, como los arts. 463.2, 464, 465 y 466.1, que se refieren a los abogados o procuradores que intervienen en un proceso o procedimiento judicial, y porque el Tít. XX se refiere a delitos contra la administración de Justicia y en sentido estricto sólo participan en ella los abogados colegiados defendiendo o representando a personas ante los tribunales.

Pero por otra parte también se puede efectuar una interpretación amplia de abogado en el art. 467 como el jurista que, o bien como colegiado defiende o incluso representa a personas en procesos judiciales, o bien las asesora y apoya jurídicamente, estando colegiado o no, en asuntos extrajudiciales, negociales, contractuales, de conciliación o mediación, en procedimientos administrativos o tributarios, etc., dado que, en cuanto a la interpretación gramatical o literal, $1^{\circ}$ ) el lenguaje cotidiano permite también designar abogado al jurista y al que realiza esas actividades extrajudiciales de apoyo jurídico $; 2^{\circ}$ ) igualmente el Diccionario de la Academia maneja el significado

38 Así, aunque posiblemente parten de que se trata de abogados colegiados, Rodríguez Devesa/Serrano, PE, 18 a , 1995, 1140 s.; González Rus, en Cobo (coord.), PE, 2. a , 2005, 985 ss., aunque en 986 insiste en que el abogado puede realizar meramente asesoramiento y no defensa o representación; Orts, en Vives/Orts/et al., PE, 2004, 975 ss. 
amplio, tanto en la primera acepción: "licenciado o doctor en derecho que ejerce profesionalmente la dirección y defensa de las partes en toda clase de procesos o el asesoramiento y consejo jurídico", como más aún en la segunda, referida a su origen etimológico: "intercesor o mediador", llegando incluso a recoger la expresión coloquial abogado de secano referida al "jurista que no ejerce"; y $3^{\circ}$ ) además, y para colmo, los propios Colegios de abogados prevén en España para los licenciados en Derecho que se colegian tanto la categoría del abogado ejerciente como la del "abogado no ejerciente", que no tiene despacho profesional ni lleva asuntos ante los tribunales y sin embargo es "abogado"; si esto es así, no parece que lo decisivo para esa condición sea el puro dato formal de la colegiación o inscripción en un colegio de abogados como no ejerciente para poder disfrutar de determinados beneficios corporativos, máxime cuando en España, hasta que entre en vigor el nuevo sistema de la Ley 34/2006, de acceso a las profesiones de abogado y procurador, para la colegiación como abogado no se exigen conocimientos teóricos y prácticos adicionales a la licenciatura en Derecho.

Siendo así, aunque la cuestión sea ciertamente discutible, considero preferible esta segunda interpretación amplia de abogado, aunque no esté colegiado, para las dos modalidades de deslealtad profesional del art. 467 por razones sistemáticas y teleológico-valorativas.

En primer lugar, aunque los arts. 463-466 se refieren a los abogados que actúan en procesos judiciales, precisamente el art. 467 se refiere al abogado que desempeña funciones no procesales. En el 467.1, junto a haber tomado la defensa o representación, se prevé que el abogado haya sólo "asesorado" a una persona, pero incluso al hablar de "defender o representar" se dice "en el mismo asunto", que no necesariamente es un proceso, sino que puede ser defensa en sentido amplio o representación en asuntos extrajudiciales, como procedimientos administrativos o negociaciones colectivas o individuales ${ }^{40}$; podría pensarse que la deslealtad con el cliente es mayor si se ha asumido una defensa judicial, pero realmente la deslealtad profesional como jurista con su cliente puede ser igualmente grave si se defienden o apoyan jurídicamente intereses contrarios en el mismo asunto aprovechándose el profesional del Derecho de la información especialísima de que dispone por su asesoramiento profesional a la otra parte. Y en el art. 467.2 basta con que el abogado perjudique manifiestamente de cualquier forma los intereses que le fueren encomendados, que nuevamente pueden ser intereses en procesos

40 La doctrina discute si la conducta activa del 467.1, una vez que se ha asesorado, defendido o representado a persona con intereses contrarios, puede ser no sólo defender o representar, sino también simplemente asesorar: en sentido afirmativo MUÑOz CONDE, PE, 17. a, 2009, 880 (seguramente por entender que asesorar también es defender intereses); en sentido tajantemente negativo dada la redacción legal (“defienda o represente”, que no añade "o asesore”) GonZÁLEZ Rus, en CoBo (coord.), PE, 2. a , 2005, 986. Si fuera más correcta esta última posición, podría considerarse como un argumento en contra de la inclusión del asesor jurídico, pero no lo es dado que se habla de defender en el mismo "asunto", que perfectamente puede ser extrajudicial. 
judiciales o en cualquier tipo de asuntos fuera de los tribunales. Eso sí, hay que partir de que ambos apartados se están ocupando de una deslealtad como jurista que asesora o apoya profesionalmente al cliente por un encargo contractual ("intereses que le fueren encomendados" en el ap. 2, asesorado o tomado la defensa o representación en el mismo asunto en el ap. 1), no por un mero favor ocasional y esporádico, en cuyo caso no habría previos deberes de lealtad profesional.

Además, aunque ciertamente el Tít. XX protege en general la Administración de Justicia, también se incluyen en el mismo figuras típicas que no están estrictamente vinculadas a la actuación de los tribunales, como la omisión de impedir o promover la persecución de delitos del art.450, el encubrimiento del 451 ss. o la realización arbitraria del propio derecho del art. 455, que afectan a una fase pre-procesal ${ }^{41}$; y del mismo modo en el art. 467 se quiere proteger y garantizar la actuación recta, fiable y leal del profesional del Derecho con sus clientes no sólo ante los tribunales sino en otros asuntos jurídicos o negociales para que no padezca tal fiabilidad profesional frente a los clientes no sólo del abogado operando en la Administración de Justicia, sino como operador jurídico y profesional del Derecho (e indirectamente por ello de la justicia, no como institución, sino como valor superior del ordenamiento jurídico y constitucional, art. $1 \mathrm{CE}$ ) en general incluso en asuntos no judiciales. Y por último, si se pretende garantizar ese interés en la correcta y fiable actuación del profesional del Derecho, tanto de asesoramiento jurídico como de representación o defensa de intereses y personas en asuntos tanto judiciales como extrajudiciales que se le encomienden, y ello lo puede hacer por igual en la actividad no judicial el abogado colegiado como ejerciente con capacidad para llevar asuntos litigiosos también en los tribunales y asimismo el jurista no colegiado como ejerciente pero que contractualmente asesora, apoya o defiende jurídicamente en asuntos fuera de los tribunales, entonces el criterio decisivo no puede ser el requisito meramente formal de la colegiación o inscripción en un colegio de abogados: sería ridículo que, de dos juristas que trabajen en una asesoría jurídica de empresa o externa pero sin ser abogados ejercientes, pudiera cometer delito de deslealtad profesional del art. 467 uno que estuviera inscrito en un colegio de abogados como abogado no ejerciente y en cambio no otro que realizara la misma conducta, pero no se hubiera molestado antes en colegiarse como no ejerciente.

Por tanto, parece más correcto interpretar que en el art. 467. 1 y 2 abogado que puede cometer deslealtad profesional es todo jurista, esté colegiado o no, que realice por encargo de un cliente labores de asesoramiento, defensa o apoyo jurídicos o incluso representación de personas o intereses en asuntos judiciales (si es abogado ejerciente) o extrajudiciales.

41 Así, siguiendo una clasificación de Quintano Ripollés, Curso DP, 1963, 570 s., LuZón PeÑa, Consideraciones sobre la sistemática y alcance de los delitos contra la Administración de Justicia, en La reforma penal y penitenciaria, Univ. Santiago, 1980, 518 (513 ss.); tb. en Estudios penales, LHAntón Oneca, 1982, 779 (777 ss.); y en Luzón Peña, Estudios Penales, 1991, 577 (573 ss.). 
e) Por lo demás, obviamente además de la responsabilidad penal el asesor jurídico incurrirá en estos casos en la correspondiente responsabilidad civil ex delicto conforme a los arts. 109 ss. CP por los daños y perjuicios materiales y morales causados a los clientes.

\section{El asesoramiento que induce a error al cliente}

\section{a) Repercusiones para asesorados y asesor}

La orientación y consejos profesionales del asesor jurídico pueden perjudicar gravemente a sus clientes de una empresa y directiva porque provoquen un error en sus miembros que les lleve a realizar un acto ilícito, y más concretamente delictivo, creyendo que no lo es. Ello generalmente no producirá responsabilidad penal en los clientes si se prueba su error y se considera que era invencible y que excluye, según que sea error de prohibición o de tipo, como mínimo su culpabilidad o incluso la parte subjetiva del tipo (dolo e imprudencia), pero como mínimo les producirá los perjuicios indudables y muy graves de una investigación criminal, de una eventual imputación durante al menos la instrucción del proceso y mientras tanto la amenaza pendiente de una condena penal. Pero según algunas posiciones, el error del cliente en algunos casos puede considerarse vencible pese a haber estado informado y aconsejado por su abogado o asesor jurídico y entonces sí podrá el cliente incurrir en responsabilidad penal, aunque sea atenuada, por el hecho objetivamente delictivo.

En ambos casos, esos graves costes y daños morales, psicológicos, reputacionales y económicos para los clientes, mucho mayores aún si llegaran a incurrir en responsabilidad penal provocada por el asesoramiento erróneo, generarán indudable responsabilidad civil para el asesor derivada de su acto ilícito o incluso delictivo. Pero además delito de deslealtad profesional dolosa o imprudente del art. 467.2 CP por perjudicar de forma manifiesta los intereses del cliente. Y después veremos (en c) si tb. responsabilidad penal como autor o partícipe del tipo delictivo objetivamente cometido por el cliente, que en caso positivo, como hemos anticipado, estará en concurso ideal con la deslealtad profesional del art. 467.2 por afectar cada delito a bienes jurídicos totalmente diversos.

\section{b) Exención de responsabilidad o no de los clientes inducidos a error}

\section{b.1) Clases de error en el cliente}

Los clientes, en este caso los directivos de la empresa -aunque con el nuevo proyecto de reforma del CP de nov. 2009 se pretende que la propia sociedad o persona jurídica pueda ser considerada responsable por negligencia en su organización si en la misma se producen delitos-, que han consultado al asesor o asesores jurídicos sobre si había problemas de ilicitud en determinada actuación o actuaciones y han sido mal informados por éste de modo que adoptan una 
decisión objetivamente equivocada, incurren en un error, según los casos, de tipo o de prohibición. Si fuera invencible, como ocurrirá en la mayoría de los supuestos, y se aprecia así por el tribunal, quedarán exentos de responsabilidad penal (incisos $1^{\circ} \mathrm{S}$ del art. 14.1 y $3 \mathrm{CP}$ ); pero si fuera vencible, los clientes tendrían en todo caso responsabilidad aunque atenuada si fuera un error de prohibición vencible (art. 14.3 inciso $2^{\circ}$ ), mientras que si fuera un error vencible de tipo, su responsabilidad por imprudencia dependerá de si está tipificada la correspondiente infracción imprudente (art. 14.1 inciso $2^{\circ}$ : "la infracción será castigada, en su caso, como imprudente").

\section{b.2) Error de prohibición en el cliente: ¿invencible o en algún caso vencible?}

Generalmente el abogado o asesor jurídico, con su información o consejos inciertos sobre la situación jurídica, provocará en los clientes un error de prohibición por hacerles creer equivocadamente que la conducta que van a llevar a cabo es lícita, error que en todo caso es relevante según el art. 14.3. O en algunos casos sufrirán al menos un error sobre la prohibición penal de la conducta, sabiendo que la misma es ilícita, pero creyendo que es sólo un ilícito extrapenal, p.ej. administrativo o civil, pero que no es penalmente típico, error que parte de la doctrina denomina de modo impreciso y confuso "error sobre la punibilidad" (cuando el elemento del delito sobre el que realmente recae es la tipicidad penal); v.gr. si el cliente asesorado en una empresa recibe la falsa información del abogado de que es ciertamente ilícito pero no delictivo, por no ser hurto ni apropiación indebida de cosa poseída, adueñarse de un paquete de títulos valores extraviados por sus propietarios, o hacer constar en el acta de una junta general societaria falsamente que asistieron determinados accionistas, explicando el asesor que sería impune por ser una mera falsedad ideológica de particular, que ha sido despenalizada en el CP de 1995, o mentir descaradamente en la publicidad de un producto atribuyéndole importantes propiedades adelgazantes de las que carece alegando que es una infracción mercantil pero nada más, cuando tales hechos constituyen realmente apropiación indebida de cosa perdida del art. $253 \mathrm{CP}$, falsedad documental del art. 392 e.r.c. el 390.1, $3 .^{\circ}$, o delito publicitario del art. 282 por poder causar la información falsa un perjuicio grave y manifiesto a los consumidores. Dicho error mayoritariamente se considera irrelevante, pero un sector minoritario consideramos que no es irrelevante y que, aunque ciertamente, al tener el sujeto pese a todo conciencia de la ilicitud, no excluirá totalmente la accesibilidad a la norma prohibitiva y la posibilidad de motivarse por ésta y por tanto no excluirá nunca la culpabilidad y no tendrá efecto eximente, no obstante sí disminuye claramente la posibilidad de motivarse por la norma al pensar que no hay prohibición penal y por ello está reducida o mermada la culpabilidad y debe apreciarse, máxime si tal error es subjetivamente invencible pero también si era vencible, una atenuante muy cualificada (art. 66.1, 2. ${ }^{\mathrm{a}}$ ) por analogía (art. 21, 6. ${ }^{\mathrm{a}}$ ) con la especial atenuación 
de pena, también por disminución de la culpabilidad, del art. 14.3 , inc. $2^{\circ}$, para el error de prohibición vencible ${ }^{42}$.

Cuando la información errónea del abogado o asesor produzca en el cliente un auténtico error de prohibición por creer que la conducta es lícita, normalmente, en la gran mayoría de los casos, será un error subjetivamente invencible porque el profano al que le ha asesorado un profesional del derecho no podrá sospechar, ni tiene por qué, que tal información es falsa o al menos errónea. La doctrina mayoritaria considera incluso que una información clara y precisa de un abogado hace siempre (subjetivamente) invencible el error de prohibición del profano asesorado, porque éste no puede juzgar la claridad de la situación jurídica o la competencia o no del abogado y no debe por tanto comprobar la habilidad y conocimientos del abogado ${ }^{43}$.

Esto es correcto casi siempre, pero no obstante puede haber casos excepcionales en que el profano podría haber sospechado que la información recibida no es correcta y por tanto su error de prohibición sea (subjetivamente) vencible y en tal caso sólo disminuya su culpabilidad y se atenúe la pena del delito doloso -dolo porque tiene conciencia de los elementos objetivos del hecho típico, de los presupuestos objetivos de la prohibición, aunque no de la prohibición: dolo objetivamente malo ${ }^{44}-$, bajándose según el art. 14.3 , inc. $2^{0}$ a la pena inferior en uno o dos grados; pero al seguir siendo doloso, y no imprudente, el hecho cometido por el cliente (ya que el art. 14.3 ha seguido la solución, no de la "teoría del dolo" de que el error de prohibición excluye el dolo, sino la de la "teoría de la culpabilidad", o sea que el error de prohibición no excluye el dolo, sino que afecta sólo a la culpabilidad45), ese hecho es punible en todo caso y no como en los errores de tipo vencibles. Así será subjetivamente vencible el error de prohibición del cliente cuando la información del asesor jurídico es tan disparatada y desatinada, aunque se formule de modo claro y preciso, que normalmente incluso al profano le puede levantar sospechas y moverle a consultar con otros asesores. Por ello, con independencia de su aplicación al caso concreto, es en principio defendible el criterio de la SAP Barcelona 12/2001, 10-1, que considera vencible el error de prohibición de una mujer que fue informada pésimamente por el abogado y pese a ello, pudiendo hacerlo, no contrastó la información con otro abogado. Y también será vencible tal error,

42 Así Luzón Peña, PG I, 1996, 463. Siguiéndome Díaz y García Conlledo, El error de prohibición: pasado, presente y futuro, LH-Torío, 1999, 357 (335 ss.); El error sobre elementos normativos del tipo penal, 2008, 163; similar Olaizola, El error de prohibición. Especial atención a los criterios para su aplicación y para la determinación de su vencibilidad e invencibilidad, 2007, 61-65. 245; Roxin, AT I, 4 ${ }^{\text {a }}$, 2006, § 21 nm. 62 ss.; PG I, 2ª 1997, § 21 nm. 60 ss.; DíAZ y García ConlleDo, LH-Torío, 1999, 362; Olaizola, El error de prohibición, 2007, 187 s.

45 Cfr. ampliamente LuZÓn PeÑa, PG I, 1996, 465 ss., 470 ss.; Olaizola, El error de prohibición, 2007, 35 ss.; Díaz y García Conlledo, LH-Torío, 1999, 335 ss.; El error sobre elementos normativos, 2008, 165 ss. 
por poderse suscitar dudas o sospechas en el sujeto aunque pese a todo cayera en el error de creer lícita la conducta, p.ej. si la información del asesor jurídico es vacilante y oscura e imprecisa, o si otro jurista le ha informado al cliente en sentido contrario, o sea de que es un hecho prohibido, o si el propio cliente, por tener algunos conocimientos jurídicos, tenía inicialmente la impresión - correcta- de que el acto era ilícito pero acaba confiando en la información incorrecta de un abogado no especialmente prestigioso ${ }^{46}$.

Dicho error de prohibición del cliente ante datos que hagan muy sospechoso o dudoso el informe del asesor será normalmente vencible, a no ser (dado que la vencibilidad o invencibilidad es aquí subjetiva, por ser un problema de culpabilidad individual) que circunstancias individuales como la poca cultura o inteligencia o extrema credulidad o estado emocional del asesorado le impidieran que se le suscitaran sospechas y en tal caso fuera subjetivamente inevitable su error y excluya su culpabilidad y le exima de pena.

\section{b.3) Error de tipo en el cliente: invencible o vencible y consecuencias}

Frente a esto, aunque esto no se suele destacar ${ }^{47}$, en otras ocasiones la información del abogado, de buena o de mala fe, provocará en su cliente un error de tipo: el desconocimiento de un elemento fáctico o normativo del tipo o la creencia errónea de que concurren los presupuestos de una causa de atipicidad, o también de una causa de justificación, que la doctrina mayoritaria considera con razón equiparado al error de tipo estricto ${ }^{48}$. Así p.ej. si el abogado le comunica al cliente la falsa información de que ha adquirido la propiedad de un paquete de acciones ajenas que el cliente tenía en depósito o administración y que por tanto esos efectos ya no son "ajenos", por lo que puede disponer de ellos vendiéndolos o donándolos (y aquí es indiferente si esa falsa apreciación sobre la ajenidad se debía a un error fáctico o jurídico del abogado, si éste actuaba de buena fe), con

46 En todos estos casos de informaciones dudosas habrá error de prohibición siempre, claro está, que el asesorado crea y confíe en la información errónea y por tanto no sea consciente de que su conducta puede ser ilícita y no lo descarte, es decir, siempre que no obre en una situación, paralela al dolo eventual, de conocimiento o conciencia eventual de la antijuridicidad. Sobre ello ampliamente RUDOLPHI, Unrechtsbewusstsein, Verbotsirrtum und Vermeidbarkeit des Verbotsirrtums, 1969, 140 ss.; RoXIN, AT I, 4 a 2006, § 21 nm. 29 ss.; PG I, 2a , 1997, § 21 nm. 28 ss.; FeliP y SABORIt, Error iuris: El conocimiento de la antijuricidad y el art. 14 del CP, 2000, 131 ss.; TRAPERO, El error en las causas de justificación, 2004, 598 s.; Olaizola, El error de prohibición, 2007, 68 ss.

47 En uno de los contados trabajos de la doc. española sobre responsabilidad penal del asesor jurídico, no centrado como otros sólo en el blanqueo de capitales, RoBles PlanAs, Riesgos penales del asesoramiento jurídico (1), LL 2008-4, 1923 ss., en 1929 Robles sólo plantea el supuesto de error del asesor sobre la calificación jurídica de los hechos, aunque luego deja planteado si ello genera en el cliente un error de prohibición o de tipo (pero sin limitar este caso al error jurídico sobre un elemento normativo del tipo).

48 Así la mayoritaria teoría restringida de la culpabilidad y la teoría del dolo, mientras que sólo la teoría estricta de la culpabilidad considera error de prohibición el error sobre los presupuestos de una causa de justificación; cfr. ampliamente TrAPERO, El error en las causas de justificación, 2004, passim; Luzón PeÑa, PG I, 1996, 469 ss. 
lo que el cliente dispone como dueño de las acciones cometiendo el tipo objetivo de la apropiación indebida del art. 252. O si un empresario transportista realiza sin saberlo el tipo objetivo del art. 345.1, "el que sin la debida autorización ... transporte ... materiales radiactivos o sustancias nucleares" porque el abogado de la empresa le comunica erróneamente que cuenta ya con la debida autorización administrativa para tal transporte, siendo irrelevante a estos efectos que la debida autorización fuera una causa de atipicidad o de justificación, e igualmente vuelve a ser indiferente, en caso de que el abogado a su vez actuara de buena fe, que el error fuera de carácter fáctico, que la autorización fuera para otra clase de transporte peligroso y lo hubiera malentendido negligentemente, o que se debiera a una falsa apreciación jurídica sobre el carácter autorizante $\mathrm{y}$ válido de una comunicación administrativa. $\mathrm{O}$ si un fabricante de alimentos o bebidas comete en error el tipo objetivo del art. 364.1, adulterar con aditivos no autorizados susceptibles de causar daños a la salud de las personas los alimentos o bebidas destinadas al comercio alimentario, nuevamente porque en su asesoría jurídica le informan incorrectamente de que un nuevo aditivo que van a incorporar está autorizado cuando no es así.

Dicho error de tipo o sobre el tipo (o "sobre un hecho constitutivo de la infracción penal" como dice el art. 14.1) excluye en todo caso el dolo en la actuación del cliente. En muchos casos excluirá además la imprudencia de éste por ser un error objetivamente invencible en cualquier cliente cuidadoso y diligente porque no haya ningún motivo objetivo para sospechar de que la información fáctica o jurídica que le proporciona el abogado no es cierta y porque aquí, a diferencia del error de prohibición, lo que se representa el cliente es una conducta que, con esos elementos representados, objetivamente no está prohibida -no una conducta objetivamente prohibida, pero que él no lo sabe- y por tanto no hay motivos para abstenerse de realizarla si no hay indicios manifiestos de que la información puede ser errónea. Tal exclusión de dolo e imprudencia por error objetivamente invencible, que no es sino una modalidad de caso fortuito, naturalmente excluye la responsabilidad criminal del cliente según el art. 14.1, inc $1^{0} 49$.

Pero en otros casos sí que habrá datos sospechosos en las circunstancias que deberían mover a un empresario precavido y cuidadoso a cerciorarse de la corrección de la información y si no lo hace, su error será objetivamente vencible y cometerá imprudencia, provocada en inicio dolosa o imprudentemente por el asesor. No obstante, tal error vencible e imprudencia supondrá sólo en unos casos responsabilidad penal para el cliente, pero en otros no (y tendrá sólo responsabilidad civil o administrativa), como reconoce el art. 14.1, inc. 2. ${ }^{\circ}$ : si tal error "fuera vencible, la infracción será castigada, en su caso, como

49 Éste habla de cualquier error invencible de tipo, sin distinguir si es objetivamente o sólo subjetivamente invencible; si sólo es subjetivamente invencible por circunstancias individuales del sujeto, pero era objetivamente vencible y por tanto imprudente, se excluye la responsabilidad pero no por falta de tipo subjetivo (de dolo y también de imprudencia), sino por otra razón: por falta de culpabilidad individual en la conducta imprudente. Cfr. Luzón Peña, PG I, 1996, 445. 
imprudente". Se recuerda que "en su caso", primero, porque una gran parte de los tipos delictivos objetivos describen la forma dolosa pero no prevén además la comisión imprudente y según el sistema de numerus clausus del art. 12 "las acciones u omisiones imprudentes sólo se castigarán cuando lo disponga expresamente la Ley"; de los ejemplos antes citados sólo en el de añadir a los alimentos aditivos no autorizados y peligrosos se castiga la comisión gravemente imprudente en el art. 366; mientras que en la apropiación indebida o en el transporte no autorizado de sustancias radiactivas no se tipifica la modalidad imprudente. Y en segundo lugar, porque incluso en los contados delitos que tipifican la modalidad imprudente, en la inmensa mayoría sólo es típica la conducta de imprudencia grave, salvo en el art. 621. 2 y 3 que castiga también como falta el homicidio y las lesiones por imprudencia leve. Con lo cual, en el resto de los delitos imprudentes, el error vencible de tipo no dará lugar tampoco a responsabilidad penal cuando la imprudencia no sea grave, es decir cuando el error no sea bastante fácilmente vencible.

\section{c) Autoría o participación dolosa o en error del asesor; clase de error y responsabilidad}

\section{c.1) Actuación de mala fe y sin error del asesor: autoría mediata o participación}

Si el asesor informa de mala fe, sin sufrir él ningún error de prohibición o de tipo y sabiendo y aceptando con dolo directo o al menos con dolo eventual provocar o poder provocar tal error en el cliente que le llevará a cometer el hecho objetivamente delictivo, evidentemente el asesor actúa con dolo y con plena culpabilidad y normalmente responderá como autor mediato doloso del hecho directamente ejecutado por el cliente. Al provocarle al ejecutor directo un error que excluye su conciencia de la significación del hecho, no sólo el error de tipo, sino según la posición más correcta también el de prohibición incluso aunque sea vencible, y por eso le excluye o restringe decisivamente los motivos para inhibirse, el asesor convierte al cliente en alguien que opera engañado como un instrumento suyo y no decidiendo consciente y responsablemente, y por tanto aquél tiene el dominio del hecho a través instrumento ${ }^{50}$.

Si el asesor es autor mediato del delito, entonces se examina autónomamente en su propia actuación si concurre el dolo como el resto de los elementos del tipo, y al no ser un mero partícipe (inductor o cooperador), no rige la accesoriedad de la participación y no está vinculado al hecho típico objetivo y subjetivo realizado

50 Sobre la autoría mediata a través de error, también de prohibición, en el instrumento cfr. Roxin, Täterschaft und Tatherrschaft, 8a , 2006, 170 ss., 194 ss.; HernándEz Plasencia, La autoría mediata en DP, 1996, 167 ss., 192 ss. En relación con la creación dolosa por el asesor de error en el cliente RoBles Planas, LL 2008-4, 1929, plantea que si es error de prohibición cabría participación punible del asesor, mientras que si es error de tipo habrá que recurrir a la autoría mediata para que responda el asesor, aunque él sostiene la peculiar posición de que en ambos casos la conducta del asesor es "una intervención punible en un hecho cometido en error". 
por el autor directo, concretamente a que el cliente haya realizado un hecho sólo imprudente o incluso fortuito. Por tanto, el asesor será autor mediato de un delito doloso y con plena culpabilidad, no sólo cuando el cliente haya realizado en error de prohibición un delito doloso pero con culpabilidad atenuada o incluso sin culpabilidad, sino también cuando, al actuar en error de tipo, haya realizado sólo un delito imprudente, o no realice el tipo subjetivo por haber imprudencia pero no modalidad imprudente punible en ese delito o incluso por no haber ni siquiera imprudencia sino caso fortuito al ser objetivamente invencible el error.

Sin embargo, en algunas clases de delitos, como en los que requieren actuación de propia mano (es discutible si ello también ocurre en los que describen expresamente una determinada forma de conducta) o en los delitos especiales, que exigen una condición o relación especial en el autor, no cabe autoría mediata, por mucho que materialmente tenga el dominio doloso del hecho, en el sujeto aquí el asesor-que no realice personalmente la conducta en el primer caso o que no tenga la cualidad específica en el delito especial ${ }^{51}$. Si ello es así, y a falta de un precepto específico paralelo al del art. 31.1 CP para la actuación en nombre de otro que ampliara la autoría mediata en esos casos en que materialmente existe el dominio del hecho pero falta un requisito típico formal, sólo cabe recurrir subsidiariamente a la participación dolosa (inducción o ooperación necesaria) del asesor en la autoría del delito por el cliente.

Ello lleva a una solución penológicamente no insatisfactoria cuando ha inducido a un error de prohibición al cliente, puesto que la actuación de éste sigue siendo dolosa (aunque inculpable o menos culpable) y por tanto la inducción dolosa al delito doloso se castiga con la misma pena del autor doloso. Pero la solución de la participación es insatisfactoria cuando se ha provocado un error de tipo en el cliente. En efecto, si éste es objetivamente vencible y se castiga la comisión imprudente de ese delito, entonces el asesor ciertamente responderá penalmente (ya que es posible la participación dolosa en una autoría imprudente ${ }^{52}$ ), pero sólo por el favorecimiento del tipo imprudente y con la pena de éste. Y aún es más insatisfactoria si el error del cliente es objetivamente vencible pero la imprudencia es leve y por eso atípica prácticamente siempre, o si no está tipificada la modalidad imprudente en el delito, o si el error es objetivamente invencible y por ello no hay siquiera imprudencia en el ejecutor directo, pues como en los tres casos la conducta del "autor" es atípica, en virtud de la accesoriedad no puede responder el asesor como partícipe y quedará impune.

51 Lo destaca respecto de los delitos especiales cuando no tiene la calificación del intraneus el asesor que engaña al cliente sobre la licitud de su actuación RoBles Planas, LL 2008-4, 1929, aunque considera que la gran mayoría de los delitos que vienen en consideración en este ámbito no son auténticos delitos especiales sino "delitos de posición” en los que el asesor puede ser autor sin la calificación requerida. 


\section{c.2.1) Información del asesor en error de prohibición: dolosa; participación}

En el caso más frecuente de error en el asesor, es decir, que induzca a error de prohibición al cliente porque él mismo sufra un error de prohibición, en la inmensa mayoría de los casos vencible precisamente por su condición de jurista (salvo que circunstancias de alteración anímica se lo hicieran personalmente invencible), en algún trabajo publicado entre nosotros sobre el tema se ha sostenido que ese error es excluyente del dolo en el nivel de la tipicidad, con lo que no será partícipe doloso del asesorado, sino a lo sumo partícipe imprudente, que mayoritariamente se considera impune, aparte de que en la mayoría de los delitos relacionados con el asesoramiento jurídico no es punible la modalidad imprudente ${ }^{53}$. Sin embargo, teniendo en cuenta que el error de prohibición vencible en la regulación del art. 14.3 no es excluyente del dolo ni da lugar a un hecho imprudente, sino a un delito doloso atenuado en su pena, para sostener en este caso lo contrario sólo se podría fundamentar argumentando que precisamente en la participación la situación es distinta de la autoría, concretamente que, al igual que en el encubrimiento se requiere que el encubridor quiera ocultar precisamente un delito, en la cooperación o inducción el dolo del partícipe ha de dirigirse justamente a favorecer un delito ajeno, y si el partícipe sufre un error de prohibición no tiene conciencia de inducir o cooperar a un delito y por tanto no actúa dolosamente sino imprudentemente si el error es vencible.

Pero esto no es ni puede ser correcto. Ya las consecuencias nos indican que esta solución sería absurda e injusta, porque al cliente que sufre error de prohibición provocado precisamente por la negligencia o incompetencia del asesor, ya hemos visto que en algunos casos se le podrá castigar aunque atenuadamente por un delito doloso si su error es vencible, mientras que al asesor jurídico que ha provocado el error y que tiene mayor capacidad y obligación de conocer la situación jurídica asombrosamente se le dejaría siempre impune como mero partícipe imprudente. Y efectivamente esta calificación no es correcta, ya que al asesor su error de prohibición tampoco le excluye el dolo en ningún caso ya que tiene conciencia de los presupuestos de la prohibición aunque no de la prohibición misma; y tiene conocimiento de inducir o de cooperar con su consejo a que el cliente realice o ejecute "el hecho", que es lo que requiere el art. 28, 2. ${ }^{\circ} \mathrm{a}$ y b, aunque él no sepa que es un hecho delictivo. Tal error vencible simplemente disminuirá su culpabilidad en comparación con la hipótesis de conciencia de la

53 Así Robles, LL 2008-4, 1929, aunque añade que si hubiera tipo imprudente, considera posible la participación imprudente (como ya sostiene en su: Participación en el delito e imprudencia; RDPCr 6, 2000, 223 ss.). La argumentación que da para excluir el dolo es tautológica y no puede convencer: "Este error merece ser calificado como excluyente del dolo en el nivel de la tipicidad (puesto que, de haberse asesorado correctamente la conducta del asesor hubiera sido calificada como típicamente permitida)". 
ilicitud, aunque al ser jurista se la atenuará menos que al profano y por ello la atenuación de la pena deberá ser menor que para el cliente.

\section{c.2.2) Información del asesor en error de tipo: no dolosa; ¿participación o autoría imprudente?}

Si el asesor sufrió a su vez un error de tipo que transmite al cliente, su conducta en todo caso no es dolosa. Como serán raros, no vamos a detenernos ahora en los contados casos en que las circunstancias hicieran a su vez objetivamente invencible el error para un buen asesor, supuesto de caso fortuito y riesgo permitido ${ }^{54}$ en el que éste no responde ni por su propia conducta ni por provocar así el error del cliente (se trata el supuesto infra en c.3). Más frecuentemente el error de tipo del asesor será objetivamente vencible y hay por ello imprudencia; pero al no realizar directamente el tipo él, sino el cliente, cabe discutir si el asesor responde por participación, o sea inducción o cooperación, en el hecho del cliente o por una autoría imprudente.

Si lo consideramos mero inductor imprudente o cooperador imprudente a una autoría imprudente del asesorado cuando se trate de un delito con modalidad imprudente tipificada, el asesor imprudente quedaría impune ya que, como considera con razón la teoría mayoritaria, la mera participación imprudente es impune (aunque sea conceptualmente posible) ${ }^{55}$. Eso significaría la sorprendente solución de tratar mejor al asesor que ha provocado el error que al cliente que lo ha sufrido. Y por supuesto si el error del cliente fuera objetivamente invencible y no hubiera por tanto imprudencia ni tipo subjetivo en su conducta, como partícipe el asesor quedaría impune por mucho que en él si hubiera imprudencia por tratarse de participación en hecho principal atípico.

Ahora bien, la conducta imprudente del asesor, al provocar el error vencible o invencible de tipo en el asesorado es realmente más que una mera participación imprudente, es auténtica autoría imprudente, en su modalidad de autoría mediata imprudente (a través de un instrumento en error imprudente o fortuito); aunque, al no tener dolo, el asesor no domina conscientemente el curso del hecho ni busca instrumentar al cliente, éste realmente opera objetivamente como instrumento ciego y por tanto la provocación imprudente del error por parte del asesor determina objetivamente y positivamente el curso del hecho y constituye autoría mediata imprudente ${ }^{56}$ a través del asesorado. Sin embargo,

$54 \quad$ Normalmente el caso fortuito, por error objetivamente invencible o fuera de error, implica también riesgo permitido; no vamos a entrar aquí en las excepciones en que tal error sólo excluye la tipicidad penal: cfr. ampliamente LUZÓN PEÑA, Caso fortuito y creencia razonable: error objetivamente invencible y consentimiento presunto, como causas de justificación o de exclusión de la tipicidad penal, en CuadDJ 2007-8, 403 ss.; y en RGDP 9, 2008, Iustel, 1 ss..

55 Cfr. ampliamente LuZÓN PEÑA, La “determinación objetiva del hecho". Observaciones sobre autoría en delitos dolosos e imprudentes de resultado, ADPCP 1989, 889 ss., 902 ss.; PG I, 1996, 507 ss.; Roso CAÑadillas, Autoría y participación imprudente, 2002, 395 ss., 594 ss. 
ésta será punible sólo en las figuras delictivas, minoritarias, que castigan la comisión imprudente, no en aquellas, mucho más numerosas, que tipifican sólo la comisión dolosa; y en los tipos que admiten la comisión imprudente, nuevamente la figura de la autoría mediata imprudente no será factible en aquellos delitos, especiales o de realización personal de la conducta, que son incompatibles con cualquier autoría mediata

Como se ve, el asesor que actuando en error vencible de tipo provoca a su vez un error de tipo en el cliente, resulta en ocasiones mejor tratado penalmente que los casos en que el error que sufre y provoca es de prohibición. Pero ello no es más que una consecuencia lógica de que en general el art. $14 \mathrm{CP}$ quiere que el error de prohibición vencible tenga un tratamiento penal más duro, con responsabilidad penal siempre, que el error vencible de tipo, que unas veces produce responsabilidad penal y otras no.

\section{c.3) Información correcta del asesor: no provocación de error o riesgo permitido}

Hay que advertir que hay casos en que, aunque el cliente realice una acción que a posteriori sea considerada como ilícita por el juzgador y en cambio el asesor le haya informado de que es dudoso pero en su opinión es lícita, tal asesoramiento realmente no induce a error de prohibición al cliente, si éste ha recibido todas las posibilidades interpretativas en la teoría y en la praxis de una cuestión controvertida e interpretable. Y si pese a todo el cliente no lo entendiera bien y le provoca un error, tal información del abogado será objetivamente diligente y se moverá dentro del riesgo permitido ex ante (o caso fortuito por ausencia de dolo e imprudencia) si proporciona toda la información necesaria de un modo comprensible sobre una cuestión dudosa, opinable y controvertida, incluyendo la posibilidad de decisiones contrarias en los tribunales, aunque luego se produzca una apreciación judicial de antijuridicidad ${ }^{57}$.

\section{Actuaciones favorables al cliente}

No vamos a dedicar especial atención, porque no presentan mayores peculiaridades, a delitos no específicos que el abogado o asesor pudiera realizar contra terceros o contra la comunidad para favorecer intereses de la empresa a la que tiene como cliente, como podrían ser amenazas o coacciones, allanamientos de morada u otros delitos contra la intimidad, sustracciones,

s.; Roso Cañadillas, Autoría y participación imprudente, 2002, 543 ss.

57 Así Kudlich, Die Unterstützung fremder Straftaten durch berufsbedingtes Verhalten, 2004, 484; Robles Planas, LL 2008-4, 1929, añadiendo con razón: "si el abogado informa al cliente sobre la presencia de líneas jurisprudenciales contradictorias o apela a razones fundadas para discrepar de una jurisprudencia consolidada en el caso concreto, no incurrirá en responsabilidad penal aunque el hecho llevado a cabo por el cliente resulte finalmente calificado como delictivo por un tribunal. Desde este punto de vista el asesoramiento será objetivamente «correcto» ex ante". 
falsedades, etc., o incluso actuaciones de obstrucción a la Justicia por abogado o procurador de los arts. 463 a 466 (como la incomparecencia injustificada provocando la suspensión del juicio, las violencias o intimidación contra otras partes o personas en el proceso, la destrucción u ocultación de documentos de la causa o la revelación de actuaciones procesales secretas) perjudicando a la Administración de justicia o a terceros en beneficio de sus clientes.

Concentraremos nuestro interés dentro de las actuaciones favorables al cliente en la posible existencia o no de responsabilidad penal precisamente por las conductas de asesoramiento en conductas del cliente que resultan delictivas o por la omisión de evitación o denuncia de las mismas.

1. Asesoramiento y favorecimiento activo de conducta delictiva del cliente. Delimitación entre participación e intervención punible y ejercicio legítimo de la profesión o al menos conducta penalmente atípica

En otros supuestos el cliente, p.ej. miembro de la presidencia o dirección de una empresa, no sufre error, sino que va a cometer conscientemente un hecho delictivo, pero antes o durante la realización del mismo cuenta con el asesoramiento o apoyo del abogado o asesor para las operaciones o para operaciones conexas. Y se discute ampliamente, sobre todo en los últimos tiempos, en la doctrina y en la jurisprudencia cuándo la intervención del asesor jurídico es una participación punible en la conducta del cliente o incluso una coautoría junto con aquélla y cuándo por el contrario tal asesoramiento y apoyo es impune porque no rebasa los límites de las acciones neutras o socialmente adecuadas o incluso legítimas que no llegan a constituir auténtica participación criminal.

Dados los límites de este trabajo, que representa una aproximación al tema, me limitaré a apuntar unas breves líneas esquemáticas sobre las posibles soluciones a esta cuestión.

a) Soluciones subjetivas: punibilidad o no de la participación según la clase de dolo en el asesor

Una parte de la doctrina distingue si, al realizar su conducta de asesoramiento o apoyo jurídico de significado en principio profesionalmente adecuado y no inequívocamente ilícito, hay dolo directo o por el contrario sólo dolo eventual en el asesor respecto del hecho de que el cliente vaya a delinquir, de modo que si hay dolo directo habrá participación punible, mientras que no la habrá si el abogado albergaba únicamente dolo eventual ${ }^{8}$. 
b) Soluciones objetivas: impunidad o punibilidad de la participación según el carácter neutro o neutral o estándar o socialmente adecuado de la aportación o por el contrario su adaptación y ajuste al concreto delito

Otro sector critica la posición anterior alegando que no es correcto establecer diferencias de punición entre el dolo directo y el eventual que la ley desconoce, y además que si la conducta y la aportación del asesor se mueve objetivamente en el plano de la neutralidad y por eso no hay deber de informarse de la situación, la podrá efectuar aunque sepa seguro de la comisión futura del delito ${ }^{59}$. Entonces se sostiene que de lo que se trata es de que si la aportación del asesor objetivamente se mantiene dentro de la actuación estándar, usual y adecuada en el desempeño jurídico profesional, incluso si simplemente tiene un carácter "neutral" (que no se inclina ni a favor ni en contra del plan delictivo), tal conducta no es una auténtica participación punible que favorezca específicamente al autor, o desde otras perspectivas, tal conducta será socialmente adecuada y no rebasará el riesgo permitido (lo que por cierto, para un sector supone que se excluye la imputación objetiva); se trata de una aplicación a la actividad del asesor jurídico de la construcción de las "acciones neutrales" que en las últimas décadas se utiliza por un sector para negar la tipicidad de la participación. Por el contrario, habrá participación punible, típicamente relevante, si la aportación del asesor jurídico a la conducta del cliente rebasa esos límites de carácter neutral, estándar y profesionalmente adecuado y se produce una conducta inequívoca de adaptación específica, ajuste o acoplamiento al concreto hecho delictivo cometido, y pasa entonces a contribuir específicamente al mismo y a integrarse en él ${ }^{60}$. Luego ya se discuten, y mucho concretas actuaciones de dar información, asesoramiento o apoyo jurídico y profesional ${ }^{61}$

\section{c) Solución que parece más correcta}

1) En principio las soluciones objetivas parecen más correctas, con independencia de la fórmula o fórmulas manejadas, porque lo que debe contar es, en primer lugar, si objetivamente la aportación del asesor facilita precisamente la actuación delictiva del cliente o meramente contribuye a la actuación general de éste o a actuaciones que rodean a la delictiva, pero no precisamente a la específicamente delictiva; y en segundo lugar, si, aunque la haga más fácil, y en esa medida sería en principio favorecimiento, no ocurrirá que ese favorecimiento objetivo está amparado de todos modos por el ámbito de las facultades inherentes al ejercicio profesional de la abogacía en sentido

$59 \quad$ Así Robles Planas, LL 2008-4, 1924.

60 Cfr. sobre todo ello, FeIJoo SÁnchez, Límites a la participación criminal, 1999, 59 ss.; Robles Planas, La participación en el delito: fundamento y límites, 2003, 290 ss.; SCHILD, Nomos Kommentar zum Strafgesetzbuch, 2. ${ }^{a}$ ed., 2005, § 27, nm. 17; concretamente sobre la conducta del asesor jurídico, RoBLes, LL 2008-4, 1924 ss.

61 Cfr. extensamente Robles, LL 2008-4, 1925-1927. 
amplio y por tanto se mueva en el ejercicio legítimo de la profesión o del derecho y del riesgo permitido -y aquí es indiferente si ello es una causa de justificación, o incluso ya una causa de atipicidad de entrada por tratarse de una aportación del abogado absolutamente normal y cotidiana y considerada correcta por todo el mundo, o sea socialmente adecuada- o si al menos es penalmente atípica por moverse en un ámbito neutro (expresión más correcta que "neutral", que se predica de personas respecto de partes en conflicto), ni positivo ni negativo, quizás socialmente tolerable. Y también parece correcto que tal carácter de permitido o al menos no prohibido penalmente desaparecerá si la información, asesoramiento, mediación o apoyo profesional se adapta específicamente a las peculiaridades precisamente de la concreta conducta delictiva, pues entonces perderá su carácter de conducta neutra o incluso adecuada y correcta para adquirir inequívoco sentido criminal.

2) Pero por otra parte, también es cierto que precisamente, y aquí está la razón de fondo de la teoría subjetiva, es perfectamente posible que el servicio jurídico del abogado tenga o conserve un carácter neutro o incluso socialmente y jurídicamente adecuado y ajustado al estándar del correcto ejercicio profesional si sólo hay dolo eventual de que el cliente podría aprovechar tal servicio jurídico para cometer un delito, y tanto más cuanto más remota, general y menos concreta sea esa posibilidad y sospecha: en tal caso se puede sostener que, ante un grado poco elevado de peligro de aprovechamiento por el cliente para cometer algún delito, los límites del riesgo permitido (y su ponderación general de intereses en favor del libre ejercicio profesional) aún le autorizan perfectamente al asesor a prestar el servicio. Y por el contrario, se puede entender que ante un peligro muy concreto, incluso práctica seguridad que da el saber que el cliente va a cometer el delito (dolo directo de segundo grado), ya se rebasan los límites del riesgo permitido: éste es ahora un riesgo elevadísimo, casi seguro, de que el cliente aproveche el servicio jurídico prestado para cometer mejor el delito y entonces ya no tiene más peso la salvaguardia de la mayor libertad en el desempeño de la profesión jurídica. El campo dudoso por tanto subsistirá en los casos de dolo eventual pero con una probabilidad elevada de que el cliente pueda utilizar el servicio para delinquir. Pero es más, si se sabe seguro que el cliente que va a delinquir va a utilizar para su ejecución concreta precisamente el servicio jurídico que le proporciona el abogado porque le remueve obstáculos para ello, entonces tal servicio o asesoramiento se estará convirtiendo precisamente en una aportación específicamente adaptada y ajustada a la concreta ejecución del delito y tal aportación adquiere por eso un sentido criminal. Ello significa que no es cierto que si la aportación del asesor se mueve objetivamente en el plano de la neutralidad y de lo ajustado al estándar profesional, la pueda efectuar aunque sepa seguro que va a ser utilizada y va a facilitar la comisión futura del delito, pues en tal caso de dolo directo la conducta del abogado pierde precisamente su neutralidad y conformidad al estándar profesional. 
3) En el campo del asesoramiento jurídico no ocurre nada diferente a lo que sucede en otros campos más elementales donde se puede ver con enorme claridad si una colaboración sigue teniendo un carácter neutro o neutral o estrictamente profesional o por el contrario adquiere un carácter inequívoco de contribución específica a un delito concreto: si en una tienda de utensilios de cocina se venden cuchillos, la venta de un cuchillo o juego de cuchillos a una persona está dentro del riesgo permitido (dado lo inconcreto, indeterminado e incierto del riesgo) y del estándar de actuación profesional correcta aunque se le suministre a una persona que se sabe que a veces actúa violentamente y por tanto el vendedor sospeche que podría eventualmente emplearlo como arma para lesionar o matar; pero en cambio si el comerciante se acaba de enterar de que el comprador quiere utilizar el cuchillo ahora mismo para ir a agredir o matar a una persona con la que acaba de tener un incidente fortísimo, entregarle en ese momento el cuchillo sabiendo esa utilización segura (dolo directo de primer o al menos de segundo grado) ya no es un acto neutro o profesionalmente correcto de un instrumento de múltiples usos, aunque entre ellos pudiera estar el criminal, sino que se convierte en la entrega precisamente de un instrumento que va a ser utilizado de inmediato como arma homicida, se adapta precisamente a las peculiaridades del concreto delito y se convierte en una contribución favorecedora o incluso decisiva para el concreto delito y por ello en una cooperación de sentido inequívocamente delictivo.

4) Si un abogado le redacta a un cliente a petición de éste un contrato simulado con otra parte que al parecer también está de acuerdo, está llevando a cabo un servicio que se mueve dentro del estándar profesional y del riesgo permitido ante un peligro remoto de utilización delictiva, pues los negocios simulados no son ilícitos por sí mismos, por mucho que sea consciente de y asuma la posibilidad general de que un contrato simulado pudiera ser utilizado para defraudar a terceros (dolo eventual), por lo que, aunque en el caso concreto el cliente utilice el contrato simulado para engañar y estafar a un tercero, el ejercicio legítimo profesional ampara al abogado de responsabilidad por cooperación en la estafa; pero si el cliente le indica al abogado asesor que va a utilizar el contrato simulado que le redactará, en virtud del cual un tercero le pagará al cliente un elevado precio por un arrendamiento de servicios, precisamente para aparentar la solvencia de la que carece y engañar a un tercero para que le financie un préstamo que no va a poder devolver, entonces hay ya la práctica seguridad (salvo que el plan fracase) de que el servicio profesional va a ser utilizado por el cliente precisamente como instrumento necesario del delito de estafa y el asesoramiento del abogado por rebasar totalmente el riesgo permitido pierde su carácter de conducta profesionalmente estándar o neutra y se ajusta precisamente a la cooperación criminal. O por citar un último ejemplo, la mediación entre partes que difieren sobre los detalles de la ejecución de un negocio, es en principio un servicio o prestación típica de la actividad de un abogado, y ello no cambia y habrá riesgo permitido incluso aunque pueda albergar alguna remota sospecha de 
que alguno de los clientes está discutiendo reparto de beneficios y costes de algo ilícito (dolo eventual), pero cambia totalmente su sentido y se convierte en una contribución inequívocamente criminal si unos abogados intervienen como mediadores en el cobro de extorsiones o rescates cuyo carácter de tal les consta; la duda podrá estar en los supuestos intermedios de no seguridad, pero sí alta probabilidad de contribuir a un delito.

5) Únicamente hay que advertir que puede ocurrir que pese a que el asesor tenga conocimiento seguro de que el cliente directivo de una empresa va a cometer un delito y el asesor le haga la prestación jurídica que le pide, la misma suponga un servicio que favorezca al cliente en otros aspectos, pero para nada le facilite, le haga más sencilla o eficaz la realización concreta del delito. En tal caso para nada habrá cooperación material con el delito, y únicamente cabría plantear en algún supuesto la hipótesis de que constituyera auxilio moral, psicológico al delincuente, o bien la cuestión de si cabe alguna responsabilidad por omisión al no evitar o denunciar la realización segura del delito que se sabe que se va a producir.

\section{Omisiones respecto de la conducta delictiva del cliente}

Por último, el asesor jurídico puede comportarse omisivamente en un sentido favorable respecto de la actuación que conoce de su cliente con un sentido delictivo, o bien que va a llevar a cabo o bien que ya ha realizado. La omisión consistiría en no poner medios para evitar o impedir los delitos del cliente o bien para denunciar los ya cometidos. Al respecto cabe apuntar solamente lo siguiente ${ }^{62}$ :

Con respecto al común de los ciudadanos, la ley penal sólo establece en el art. $450 \mathrm{CP}$ el deber genérico de impedir o hacer impedir por las autoridades determinados delitos muy graves, concretamente contra la vida, la integridad y salud, la libertad o la libertad sexual, además de la previsión de la omisión del deber de socorro a personas en peligro manifiesto y grave del art. 495. Si en esos casos el abogado supiera que sus clientes iban a cometer o estaban cometiendo alguno de esos delitos y no actuara para evitarlo, incurriría en esas omisiones propias, suponiendo que no debieran ceder en caso de colisión con sus deberes de secreto profesional y de defensa en sentido estricto (colisión de deberes no resuelta legalmente, pero en la que probablemente prevalece el deber de salvar bienes personalísimos cuando aún están en riesgo concreto, mientras que si se trata de denuncia de hechos pasados y evitación de riesgos futuros genéricos, seguramente prevalecerán los deberes de secreto y de defensa). Pero fuera de ellos, sólo habría posible responsabilidad penal por omisión si la ley estableciera deberes especiales para determinados profesionales, o bien deberes

62 En lo que expongo a continuación comparto plenamente y sigo el planteamiento de Robles Planas, LL 2008-4, 1929-1931. 
de abstención o negativos, o bien deberes específicos de actuación positiva, de garantía.

Los deberes específicos de abstención, en este caso de prestar su colaboración incluso lícita, se pueden imponer a algunos sujetos o profesionales que en la doctrina anglosajona reciben el nombre de "gatekeepers" o guardapuertas, vigilantes de puerta o guardianes, deberes que notiene el asesor jurídico, mientras que se sostiene que p.ej. le incumben al Notario por su función de controlador de la legalidad para denegar la autorización de una escritura si encuentra indicios fundados de ilicitud ${ }^{63}$. Y en cuanto a los deberes jurídicos específicos de actuación positiva para garantizar o proteger bienes jurídicos frente a todos o a ciertos peligros, es decir los deberes de garantía, que según el art. $11 \mathrm{CP}$ pueden dar lugar a comisión por omisión si además la infracción equivale a la causación activa, y que de lo contrario podrán dar lugar en todo caso a figuras agravadas de omisiones puras de garante si existe la correspondiente previsión típica, tampoco los asesores jurídicos, a diferencia de algunas autoridades o funcionarios encargados específicamente de prevenir y perseguir delitos, tienen deberes específicos de garantizar la incolumidad de los bienes jurídicos ajenos frente a actuaciones de sus clientes.

Máxime cuando sólo en alguna figura delictiva muy concreta como el blanqueo de capitales la ley de prevención del blanqueo (art. 2.2 d L 19/1993, de 28-12 tras su redacción modificada por L 19/2003, de 4-7) establece una obligación específica para diversos profesionales como notarios, abogados y procuradores de comunicar operaciones susceptibles de constituir blanqueo al servicio ejecutivo de la Comisión de Prevención del Blanqueo de Capitales, pero cuya omisión sólo es infracción administrativa salvo que la conducta del profesional encaje además directamente en el art. $301 \mathrm{CP}$. E incluso en ese ámbito especial, dicha obligación administrativa de colaboración con la autoridad está exceptuada por el art. 3.4, párr. penúlt. de La L 19/1993 cuando los profesionales reciban la información de o sobre un cliente al determinar la posición jurídica en su favor o al desempeñar su misión de defensa o representación del cliente en relación con procedimientos administrativos o judiciales, es decir, cuando se considera prevalente el derecho de defensa concreta ${ }^{64}$.

\section{Apéndice: Resoluciones Jurisprudenciales}

\section{Sentencias sobre conductas de prestaciones neutras o de cooperación} delictiva en diversos campos

63 Así Silva SÁnchez, en Judicatura y notariado ante los delitos económicos, 2006, 181 ss. (164 ss.); Robles Planas, LL 2008-4, 1930, 1932 n. 28.

64 Destaca todo lo anterior RoBLES, LL 2008-4, 1930, pero citando de modo impreciso la numeración de los preceptos indicados. 
- SAP Madrid 19-4-2002 (ponente D. Alb. Jorge Barreiro). Se trataba de la venta de un garaje de una sociedad a otra. La mitad del pago se efectuó mediante un cheque antes de formalizar la escritura pública. Sucedió que se formalizaron dos escrituras públicas en un mismo día, una en la que intervino una persona interpuesta (que recibió su contraprestación) y en la que consta un precio de venta muy inferior y otra, acto seguido, en la que el testaferro vende al comprador real por el precio pactado. El Juzgado de lo Penal condenó a los tres por un delito fiscal. La AP revoca la condena del comprador -como cooperador necesario- apelando a la teoría de las conductas neutrales o neutras:

«Sin embargo, y tal como ya se ha razonado, ese favorecimiento causal de un hecho delictivo muy posterior en el tiempo no es suficiente para calificar la conducta del comprador como una participación por cooperación necesaria en el tipo penal. Pues la acción neutral y socialmente adecuada del recurrente no puede convertirse en un ilícito penal contra el bien jurídico (la Hacienda Pública) por el mero hecho de que el acusado conociera la posibilidad, más o menos elevada, de que el vendedor acabara incurriendo en una conducta fraudulenta. Tal posibilidad, o incluso probabilidad, no le impedía al acusado firmar la escritura pública con la persona que aparentaba ser un testaferro, ya que ello supondría imponerle un deber específico de obstaculizar la posible acción delictiva del autor dejando de suscribir la escritura. Tal limitación de la libertad del comprador en el ámbito del tráfico jurídico entendemos que no resulta acorde con el carácter fragmentario y subsidiario del Derecho penal. Y es que, a fin de cuentas, el acusado actuó dentro de los márgenes del rol social del comprador, realizando una conducta que tenía un sentido social propio y legítimo, sin que pudiera en modo alguno contemplarse desde una perspectiva unívoca o inequívocamente delictiva.»

-STS 21-2-2005 (ponente Sr. Maza). Se absuelve a la compañera sentimental del miembro de una organización terrorista que traía a su casa ropa de un secuestrado para que aquella la lavara y que prestó un vehículo a su marido para liberar al secuestrado. La sent. declara:

«El mero conocimiento de la comisión del delito y la pasividad ante ello, excepto en los concretos supuestos de responsabilidad derivada de la ocupación de una específica posición de garante, legalmente prevista, no alcanza a constituir una forma de participación típica en esa comisión (...) Semejante actividad, el lavado de ropa, nada añade ni aporta al delito, que se hubiera cometido, y de hecho se cometió, con independencia e indiferencia absoluta respecto de aquélla (...). Con ello (el prestar el vehículo), lo que en realidad se facilitaba no era la comisión de la infracción, precisamente, el término de la situación delictiva a la que se hallaba sometido la víctima.»

-STS 34/2007, de 1-2 (ponente Sr. Bacigalupo), casa la condena por delito de blanqueo de capitales doloso al testaferro que prestó su nombre para la compra de un inmueble y se le condena por su modalidad imprudente. Se afirma: 
«La participación en un negocio jurídico simulado, en principio, no es por sí un hecho típico ni penalmente relevante (...) En realidad se puede considerar un acto neutral desde el punto de vista penal (...) A estos fines la teoría y algunas jurisprudencias europeas han elaborado diversos criterios para establecer las condiciones objetivas en las que un acto "neutral" puede constituir una acción de participación. En este sentido se atribuye relevancia penal, que justifica la punibilidad de la cooperación, a toda realización de una acción que favorezca el hecho principal en el que el autor exteriorice un fin delictivo manifiesto, o que revele una relación de sentido delictivo, o que supere los límites del papel social del cooperante, de tal forma que ya no puedan ser consideradas como profesionalmente adecuadas, o que se adapte al plan delictivo del autor, o que implique un incremento del riesgo, etc. (...) No obstante, la acción del testaferro implica siempre tomar parte en un acto, que aunque no es en sí mismo delictivo, conlleva un ocultamiento que, en ocasiones, puede aumentar el riesgo de comisión de un delito, como ocurre en los casos en los que se lo lleva a cabo sin una explicación objetiva plausible de la simulación, es decir, fundada en causas manifiestamente ilícitas. En tales casos el acto neutral deja de serlo, pues tiene una relación de sentido delictivo. Cuando la cooperación en ese hecho no es dolosa, el art. 301.3 CP exige al que coopera prestándose a la simulación que obre con especial cuidado de no favorecer un delito de los autores. Es evidente que el recurrente, cuyo dolo, como se ha visto, no ha sido demostrado, no ha tomado ninguna medida de precaución para que su participación no favoreciera la comisión del delito o no aumentara el riesgo de la misma.

-STS6 de marzo de 2007 (ponente Sr. Bacigalupo). Absuelve al policía instructor de un atestado del delito de denuncia falsa, que hizo constar en el atestado la declaración de otro agente imputando síntomas de embriaguez inexistentes en un detenido. La sent. afirma:

«El instructor no ha generado un peligro desaprobado, pues no es garante de que las personas que declaran en su presencia lo hagan verazmente (...) Es cierto que, desde el punto de vista puramente causal, sin su actuación el delito formalmente no se hubiera cometido, pero se trata, en todo, caso de una acción neutral»

\section{Sobre el carácter de participación criminal o no de la cooperación del asesor jurídico}

-SAP Navarra 28-4-200O (ponente Sr. Erice Martínez) . Condena al asesor sobre los siguientes hechos probados: «Doña Ana Rosa P. y don Roberto S., venían dedicándose en su establecimiento al alquiler de $\mathrm{CD}$, cuando recibieron una comunicación de AFYVE poniendo en su conocimiento que debían cerrar el local, dado que dicha actividad era ilegal, tras efectuar una primera consulta con otro Letrado, recibieron un segundo requerimiento, momento en que solicitaron consejo de la propietaria de otro establecimiento dedicado al mismo fin, quien les puso en contacto con don Óscar F.; éste les ofreció informarles sobre la forma 
de "poder funcionar legalmente" a cambio de un millón de pesetas y el pago de 30.00o pesetas mensuales por la llevanza de la contabilidad; aceptaron y según sus indicaciones crearon una asociación cultural sin ánimo de lucro, de la que no formaron parte y que posteriormente alquiló el local a otra asociación creada por doña Ana Rosa P. y don Roberto S. para su objetivo social que era el alquiler de $\mathrm{CD}$, siendo éste el medio y motivo de que continuasen su actividad, ya que en otro caso hubiesen cerrado el negocio, según sus propias manifestaciones. Así las cosas no cabe estimar las alegaciones formuladas en este punto, ya que la labor de asesoramiento realizada por el recurrente fue condición sine qua non para la continuación del negocio con la citada forma legal, dado que sin la misma sus propietarios hubiesen cerrado el establecimiento y cesado en su actividad, una vez que fueron reiteradamente requeridos para ello por AFYVE; no cabe por tanto mantener que nos encontramos ante un mero asesoramiento sobre la licitud o no de la actividad, el cual había sido ya realizado con otros letrados, sino de la puesta en marcha de una serie de actuaciones para otorgar una forma legal y ficticia a la actividad que se desarrollaba, facilitando así su continuación pese a que se conocía su ilicitud, sin que se realizase por parte de don Óscar F. un acto aislado de asesoramiento o emisión de un dictamen, tal y como se afirma, ya que a partir de esta nueva etapa del negocio una vez seguidas sus instrucciones el Letrado continuó en relación con el negocio, ya que llevaba la contabilidad del mismo recibiendo por ello la cantidad de 30.000 pesetas mensuales».

-SAP Madrid, 11-4-2001 (ponente Sr. Martínez Lázaro): «otro tanto hay que decir en relación con el apelante Sr. S. B. Aunque en el recurso se intenta presentar como un mero asesor externo a la empresa, lo cierto es que trabajaba en la misma, y que conforme a las declaraciones del otro acusado realizaba toda la contabilidad. Es dato de especial trascendencia el que era, además, socio de la citada empresa con un $44 \%$ de las acciones. Si como socio participaba con el reparto de los beneficios no es creíble que como contable pudiese desconocer hasta tal punto la marcha de la sociedad y no advirtiese que estaba realizando una declaración con base en facturas que reflejaban gastos inexistentes, por cuantía superior a cien millones de pesetas. Es evidente que la existencia de dichos gastos disminuía su participación en el beneficio social y siendo él el encargado de la contabilidad, obviamente tenía la posibilidad de conocer si gastos tan elevados se correspondían o no a la realidad».

\section{Actuaciones de cooperación muy específica, al margen del estándar} profesional normal

-STS 16-2-2001 (ponente Sr. Abad) : « La actividad de Juan Cruz Jesús U. V. supera la mera actuación contable en la que el sujeto que la lleva se limita a recepcionar los documentos precisos para ser reflejados en los distintos libros y registros, dependiendo dicho suministro exclusivamente de la empresa y su supervisión de los responsables de la misma, lo que impediría admitir que por su condición de asesor fiscal y contable asumiese como obligación personal 
la responsabilidad de que todo lo que refleja en los libros y declaraciones efectuadas para las empresas en las que presta sus servicios sean fiel reflejo de la realidad económica de la empresa, al no disponer directamente de la información necesaria para realizarlo. Su actuación va más allá, llegando a proponer a los restantes acusados la inclusión en la contabilidad de facturas falsas que él mismo les suministra con la intención de reducir al máximo las cantidades impositivas a las que venían obligados (como el mismo acusado viene a reconocer), y conociendo en todo momento el carácter ficticio de las operaciones que refleja no sólo en los libros de contabilidad, sino en las declaraciones fiscales que redacta y presenta. Es decir, se configura como un auténtico cooperador necesario al realizar una actividad imprescindible, en pactum sceleris con los restantes acusados, para la perpetración del ilícito penal imputado por el Abogado del Estado y realizar actos materiales, conociendo la ilicitud de su actuación, que logra la consumación del tipo penal».

-STS 3-10-2005 (ponente Sr. Granados Pérez): «el recurrente desempeñó un papel crucial, como se ha dejado antes expresado, en cuanto fue el asesor inmobiliarioy jurídico de los otros dos acusados, proporcionando los documentos privados de promesa de compraventa, acudiendo a reuniones celebradas con perjudicados, percibiendo cantidades de los compradores y firmando recibos o estando presente, como aparece recogido en algunas de las operaciones (...); y asimismo intervino de enlace con las inmobiliarias, facilitó los inmuebles que sirvieron para la materialización del engaño y actuó en la práctica como socio de la entidad Esvesi, SL.». 